\section{Simulation of Groundwater Contamination by Leakage From Waste-Filled Mine}

Rudarsko-geološko-naftni zbornik

(The Mining-Geology-Petroleum Engineering Bulletin) UDC: 622.2

DOI: 10.17794/rgn.2021.5.5

Preliminary communication

\author{
Mojtaba Dehqani Tafti'; Faramarz Doulati Ardejani ${ }^{2}$; Mohammad Fatehi Marji ${ }^{3}$; Yousef Shiri ${ }^{4}$ \\ ${ }^{1}$ Shahrood University of Technology, Faculty of Mining, Petroleum and Geophysics Engineering, Shahrood, Iran, \\ mojtaba.dehqani.t@gmail.com \\ ${ }^{2}$ School of Mining, College of Engineering, University of Tehran,Tehran,Iran,fdoulati@ut.ac.ir \\ ${ }^{3}$ Department of Mining and Metallurgical Engineering, Yazd University, Yazd, Iran, mohammad.fatehi@gmail.com \\ ${ }^{4}$ Shahrood University of Technology, Faculty of Mining, Petroleum and Geophysics Engineering, Shahrood, Iran, \\ yousefshiri@shahroodut.ac.ir
}

\begin{abstract}
Mining wastes are a great source of pollutants. Open pit backfill materials can be found as waste rock and tailing. The aim of the current study was the investigation of the contaminant transportation pathways by groundwater flow from these waste materials through heterogeneous porous media. Numerical Lattice Boltzmann Method (LBM) was used for examining the effects of different factors on pollutant transportation through groundwater beneath waste materials. Grain size, vertical and horizontal fractures, and hydraulic pressure gradient were the factors that had been considered. The results showed that contaminant transportation by the groundwater flow from the waste materials through porous media depends on the primary and secondary matrix porosity of open pit materials, heterogeneity in permeability of the aquifer rock, and hydraulic head of the groundwater.
\end{abstract}

Keywords:

Lattice Boltzmann Method (LBM); contamination back-diffusion; low-permeable lenses; aquifer remediation; dual permeable medium (DPM).

\section{Introduction}

In mining operations, large quantities of waste materials are backfilled into abandoned pits. These wastes, which contain tailings or waste rocks, are stored in open pits or in underground stops (European Commission, 2009; Li, 2013). Disposal of the wastes are in low permeable porous media near or around the mines, where the groundwater table is very deep and molecular diffusion is not an effective process. However, it has some environmental pollution problems (Medunić et al., 2018; Obaje et al., 2019). Sometimes, mine wastes or tailings contain reactive sulphide minerals that can be oxidized and cause metal leaching and acid mine generation. These fluids can migrate and contaminate aquifers (Sedighi and Mohammadi, 2018) and therefore, the safe disposal of these materials is vital (Aubertin et al., 2002; European Commission, 2009). Environmental conditions are not constant, and years after a mine is abandoned, the groundwater level may rise, and also low permeable rocks may be fractured. In these conditions, generated acids and metal leaching fluids contaminate groundwater aquifers and remedial methods become necessary (Therrien and

Corresponding author: Faramarz Doulati Ardejani

fdoulati@ut.ac.ir
Sudicky, 1996; Molson et al., 2012; Maghsoudy et al., 2019; Shahhosseini et al., 2020).

Most soils and rocks in the mining site exhibit different spatial heterogeneities. Preferential flow pathways were investigated in many studies due to the textural, geometrical, and structural properties of domains, such as joint, wormholes, inter-aggregate fissures, root channels, fingering, and funnelled flow (Hobbs, 1967; Ehlers, 1975; Bouma, 1981; Brusseau and Rao, 1990; Kung, 1990; Vervoort et al., 1999; Shiri et al., 2018). Experimental investigation of fluid flow in porous media is costly and inaccessible in some cases. In this situation, computational fluid dynamics are used to study the interactions between fluids and solid matrix in industries, such as in oil and gas recovery, and in mining operations (Safari et al., 2017, 2020; Kostenko et al., 2021).

There are several models to describe fluid flow in porous media. They can include: (1) a dual-porosity model in which the porous medium has two domains; each one has a unique hydraulic and transportation property for fluid flow. In a dual-porosity model, fluid can flow in both domains, and there is no immobile fluid in the porous media; (2) dual-permeability model in which the matrix domain has a storage capacity and the fracture domain has a mobility role. There is a shape factor that 


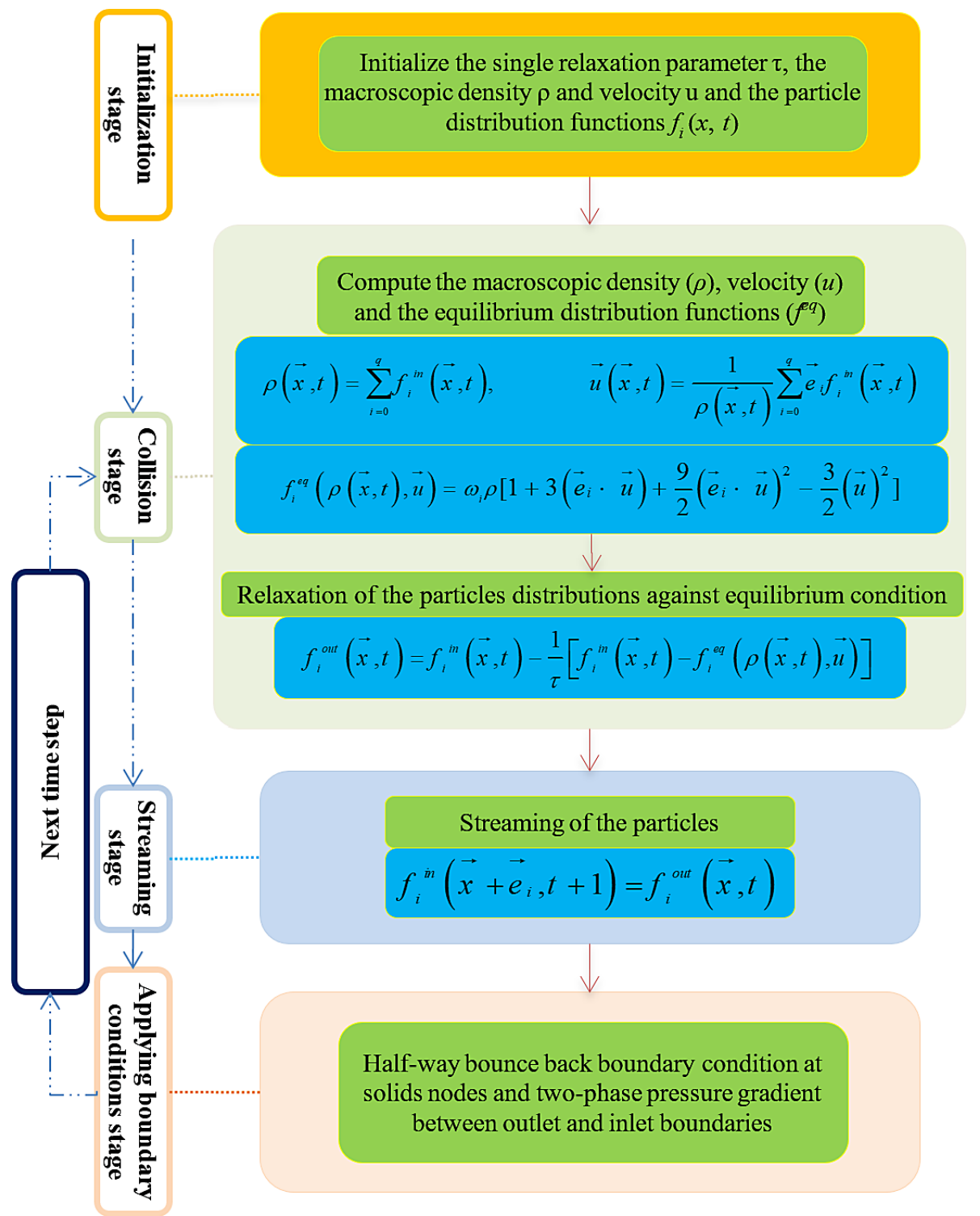

Figure 1: Basic algorithm of the lattice Boltzmann method

links these two domains with each other (Barenblatt et al., 1960). In a dual permeability model, two different transport equations are defined and solved for the high permeable and low permeable domains. They are linked for solutes (fluid) exchanges by transfer term (Gerke and Van Genuchten, 1993); (3) direct simulation like the current study, in which a single sophisticated equation is used for fluid flow in both the matrix and fracture domains (Zhou et al., 2004). There are several models to describe the effect of heterogeneity in fluid flow. They can include: (1) a Representative Elementary Volume (REV) model in which a fractured porous medium is considered equivalent with average hydrogeological properties; (2) a Discrete Fracture Network (DFN) in which each fracture is simplified and preserved its hydraulic properties; (3) real geometry simulation with methods like the Lattice Boltzmann Method (LBM), in which fluid flow in the complex porous media is simu- lated by the probability distribution function of fluid velocity (Aidun and Clausen, 2010; Shiri et al., 2018; Shiri and Hassani, 2021; Shiri and Shiri, 2021).

The purpose of this study was the investigation of contaminant transport from an open pit through the low permeable base rock with heterogeneity in permeability. Two scenarios of waste disposal in an idealized open pit, including low-permeable tailings and high-permeable mine waste rocks, were investigated. Numerical pseudopotential LBM was used for this purpose.

\section{Material and Methods}

In this study, contaminant transports from two types of waste materials stored in the open pit mines were investigated. The conceptual model was based on an open pit mine in Abitibi, Quebec, Canada. The first type of waste materials in the open pit belonged to a mining op- 
eration with a coarse-grained size distribution. The other type of waste materials in the open pit originated from a milling process, and had a fine-grained tailing. When the mine was active, the water table was held at a low level below the pit by the dewatering process. However, in some cases, it was naturally in low levels and waste materials were stored inside the pit. Years after the mine was abandoned, the water table rose up. In this condition, the open pit mine containing waste materials acted as a source for pollution for the aquifer. Joints are the most common structures in the earth surface that make heterogeneous porous media and its effects on the pollutant migration in this mine were examined. Joints are usually perpendicular to the bedding and the main mechanism of joints is cracking due to far-field extension (Hobbs, 1967). In the current study, the preferential pathway of contaminant transport from open pit through heterogeneous fracture porous media was investigated by LBM.

\subsection{Numerical method}

In this study, pseudo-potential Lattice Boltzmann method (see Figure 1) was used to study contaminant transport in the porous media. This method has been introduced and extended by Shan and Chen (Shan and Chen, 1993; Shiri et al., 2018). In this method, particle density in a regular lattice has a probability value between 0 and 1. Among several models of LBM, the D2Q9 model with Bhatnagar-Gross-Krook (BGK) approximation was used in the current study. In each node, there are nine velocity components. All of them are updated in the time marching process based on their interaction with their neighbourhood lattice nodes (see Figure 1).

The D2Q9 model of LBM can be expressed as follows (Guo et al., 2000):

$$
e_{k}=\left\{\begin{array}{lc}
(0,0) & \mathrm{k}=0 \\
(1,0),(0,1),(-1,0),(0,-1) & \mathrm{k}=1,2,3,4 \\
(1,1),(-1,1),(-1,-1),(1,-1) & \mathrm{k}=5,6,7,8
\end{array}\right.
$$

If it is supposed that $f_{k}(x, t)$ is a positive real number for fluid density distribution function at node $x$ and time $t$, the fluid distribution function $\left(f_{k}(x, t)\right)$ in time and space domain would be defined as follows:

$$
\begin{aligned}
& f_{k}\left(x+e_{k}, t+1\right)=f_{k}(x, t)+\Omega_{k}(x, t) \\
& \Omega_{k}(x, t)=-\frac{1}{\tau}\left[f_{k}(x, t)-f_{k}^{e q}(x, t)\right]
\end{aligned}
$$

Where, $\Omega$ is a collision operator. $\tau$ is the relaxation time and $f_{k}^{e q}$ represents the equilibrium state of the fluid distribution function and is determined as follows:

$$
\begin{gathered}
f_{k}^{e q}(x, t)=w_{k} \rho(x, t)+ \\
+\rho(x, t) w_{k}\left[3 \frac{\left(u(x, t) e_{k}\right)}{c}+4.5 \frac{\left(u(x, t) e_{k}\right)^{2}}{c^{2}}-1.5 \frac{|u(x, t)|^{2}}{c^{2}}\right]
\end{gathered}
$$

Where density, velocity, and weights are (Guo et al., 2000):

$$
\begin{gathered}
\rho(x, t)=\sum_{k} f_{k}(x, t) \\
u(x, t)=\sum_{k} f_{k}(x, t) e_{k} / \rho(x, t)
\end{gathered}
$$

Where:

$k-$ index for distribution components,

$e_{k} \quad-$ identity velocity components in any lattice nodes,

$f_{k}(x, t) \quad$ - fluid distribution function,

$x \quad$ - lattice node position,

$t \quad-$ time (ts),

$\Omega \quad-$ collision operator,

$\tau \quad-$ relaxation time value,

$f^{(e q)}(x, t)$ - equilibrium fluid distribution function,

$\rho(x, t) \quad-$ density of fluid $\left(\mathrm{gr} / \mathrm{lu}^{3}\right)$,

$u(x, t) \quad-$ total velocity (lu/ts),

$w_{i} \quad-$ weight of any velocity components in any lattice nodes of D2Q9 model,

c $\quad-$ sound speed in LBM.

\subsection{Porous media}

Figure 2 shows the schematic view of a conceptual model of an open pit mine, which was based on an open pit mine in Abitibi, Quebec, Canada. Sequential events in porous media were as follows: initially, groundwater flowed through the low permeable homogeneous base rocks. Then, porous media were changed by induced fractures (joints) and caused horizontal and vertical heterogeneities. Finally, the open pit surface was in contact with rainfall, and rains washed the waste material. So, rainfalls were a continuous source of solutes that can could pollute aquifers. In the current study, the role of heterogeneity in permeability, low permeable tailings, and high permeable waste materials in aquifer contamination was investigated by LBM simulation. Three types of heterogeneities in permeability, including homogeneous, vertical fractures, and a combination of vertical and horizontal fractures were investigated. In all models, the width and position of the fractures were random. Fractures were randomly generated in horizontal and vertical direction on the homogenous model with the dimension of $590^{\times} 1570$ lattices. The volume of the fractures were 59 horizontal lattices and 159 vertical lattices. Six scenarios

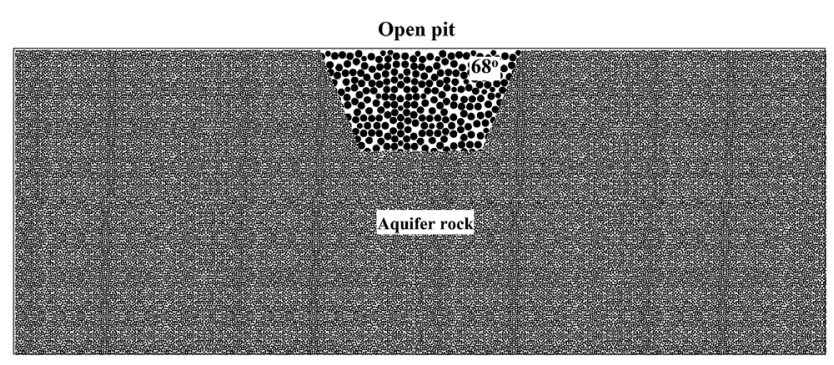

Figure 2: Schematic representation of an idealized open pit model 
Table 1: LBM parameters of all simulations

\begin{tabular}{|l|l|l|l|l|l|l|}
\hline $\begin{array}{l}\text { LBM } \\
\text { model }\end{array}$ & $\begin{array}{l}\text { Lattice } \\
\text { dimension (lu) }\end{array}$ & $\begin{array}{l}\text { Total } \\
\text { iteration }\end{array}$ & $\begin{array}{l}\text { Relaxation time } \\
\text { (dimensionless value) }\end{array}$ & $\begin{array}{l}\mathbf{G}_{\text {Cohesion }} \\
(\text { dimensionless value) }\end{array}$ & $\begin{array}{l}\text { Density of aquifer } \\
\left(\mathbf{m u . L u}^{-3}\right)\end{array}$ & $\begin{array}{l}\text { Density of } \\
\text { contaminants } \\
\text { (mu.Lu }^{-3} \text { ) }\end{array}$ \\
\hline D2Q9 & $590 \times 1570$ & $1^{\prime} 250{ }^{\prime} 000$ & 1 & 3 & 1 & 1.1 \\
\hline
\end{tabular}

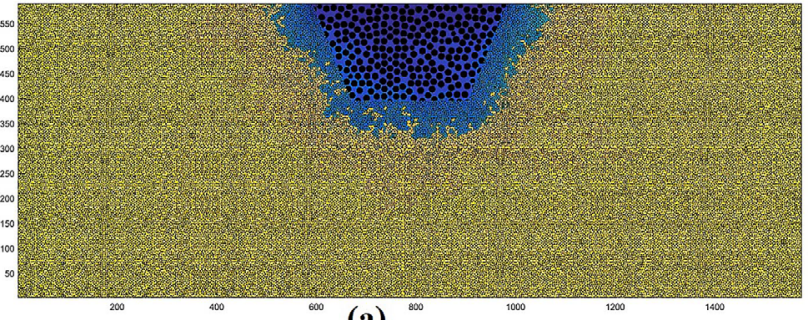

(a)

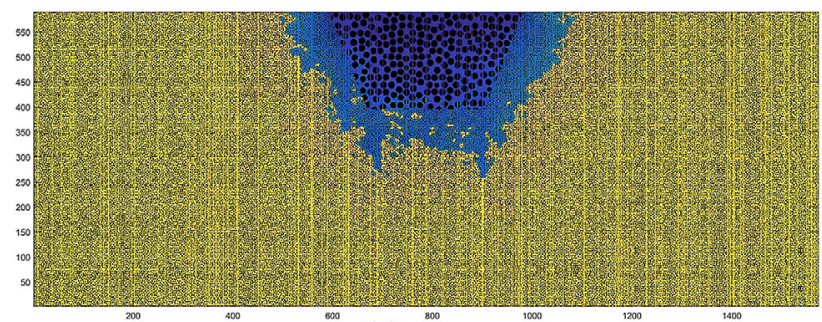

(c)

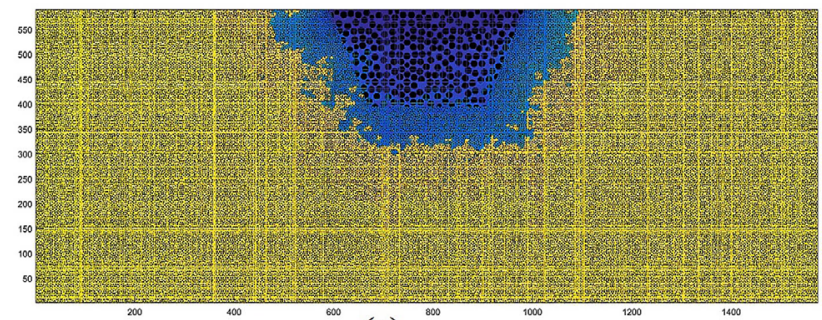

(e)

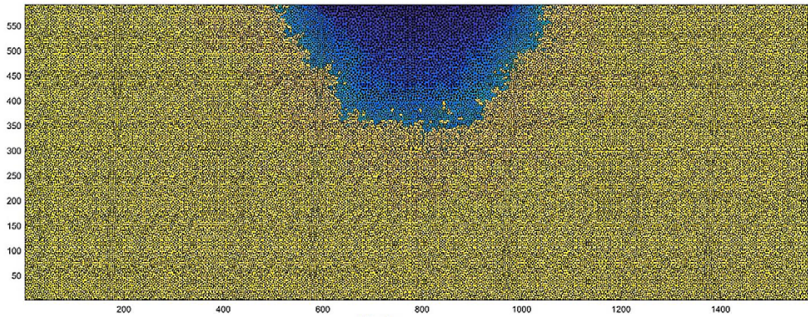

(b)

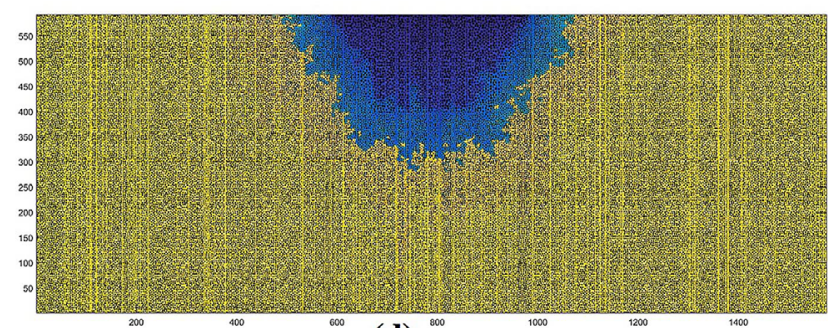

(d)

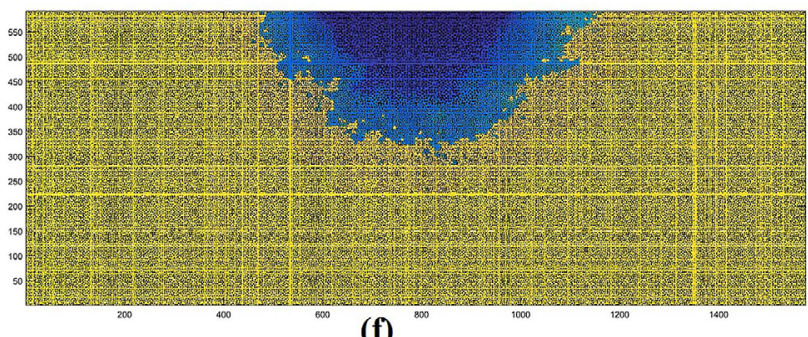

(f)

Figure 3: The effect of heterogeneity in permeability on contaminant transport at time steps of 25'0oo, (a) waste rock within homogeneous aquifer rock material, (b) tailings within homogeneous aquifer rock material, (c) waste rock in vertical fracture of aquifer rock material, (d) tailings in vertical fracture of aquifer rock material, (e) waste rock in horizontal and vertical fractures of aquifer rock material, (f) tailings in horizontal and vertical fractures of aquifer rock material

of "waste-open pit" within the homogeneous (WH), vertical fractures (WVF), and a combination of horizontal and vertical fractures (WHVF) porous media, and also similarly in "tailings-open pit" with the abbreviations of TH, TVF, and THVF, were simulated. The results showed the effects of underground heterogeneity and a type of waste material on the aquifer contamination.

\subsection{Boundary conditions and initial values}

The dimensions of the LBM models were $590 \times 1570$ lattice units. The slope of the open pit wall was $68^{\circ}$. The depth of open pit from surface was $1 / 3$ of the total depth (197 lattices). The initial porosity of the entire porous media was 0.45 . The grain size of the aquifer, tailings, and waste rocks were 200,300 , and $1000 \mu \mathrm{m}$, respectively. Hydraulic conductivity values of the waste rocks, tailings, and aquifer material were 500, 50, and 25 millidarcy $\left(=\times 9.8 \mathrm{e}-10 \mathrm{~m}^{2}\right)$, respectively. Residual water saturation of the porous media was 0.06. Due to the constant rainfall, the top surface of the pit was considered as a continuous source of water supply. The pressure gradient from both the left side to the right side, and from the top side to the right side altered the flow path with the same pressure gradient and a constant pressure gradient of 0.4 mu.lu $\mathrm{u}^{-3}$ (Huang, 2016) was applied between them. Halfway bounce-back boundary condition was applied between the fluid and solid interface (Jahanshaloo et al., 2016). The density of water was $1 \mathrm{mu} \cdot \mathrm{lu}^{-3}\left(\mathrm{~g} / \mathrm{cm}^{3}\right)$ and the density of polluted water was $1.1 \mathrm{mu}^{-\mathrm{lu}^{-3}}(\mathrm{~g} /$ $\left.\mathrm{cm}^{3}\right)$. The gravity force in all simulations was 0.0001 lu.ts ${ }^{-2}\left(9.81 \mathrm{~m} / \mathrm{s}^{2}\right)$. The parameters of LBM used in all simulations are given in Table 1.

\section{Results and Discussion}

The effect of heterogeneity in permeability on solute transport in the open pit mine containing low and high 


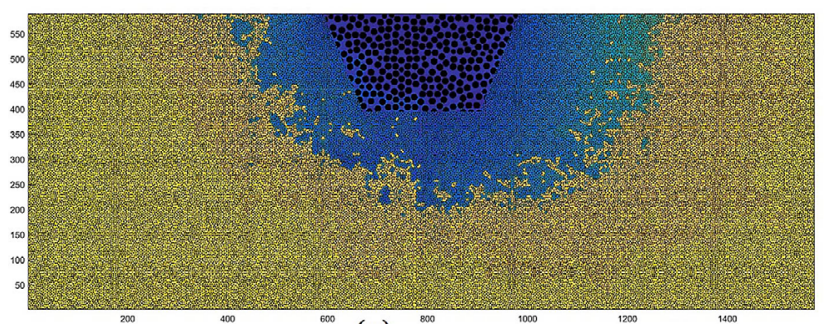

(a)

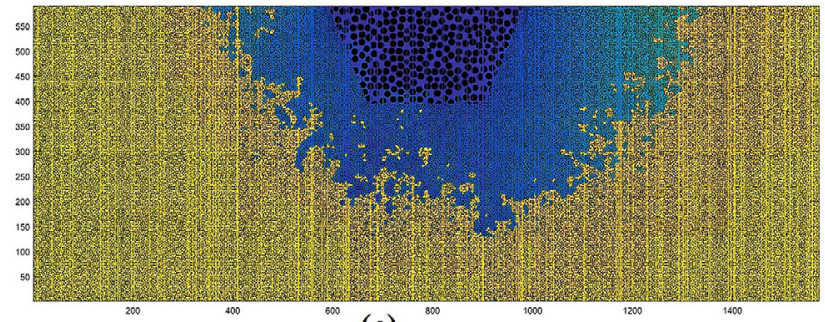

(c)

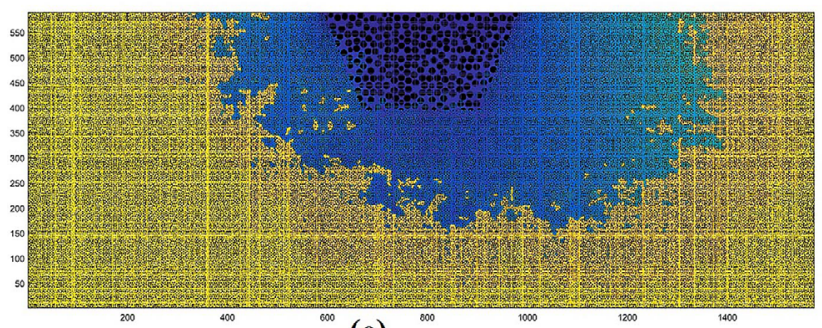

(e)

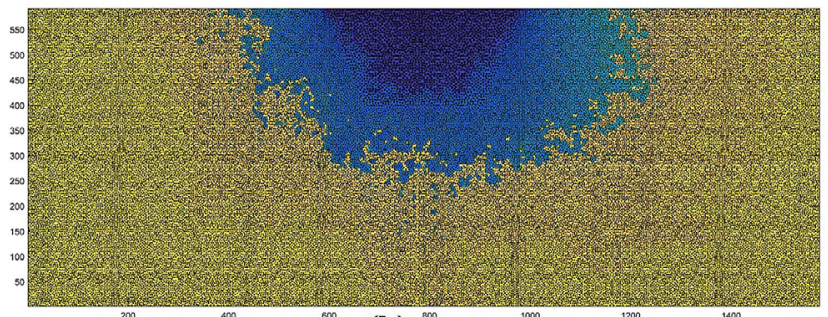

(b)

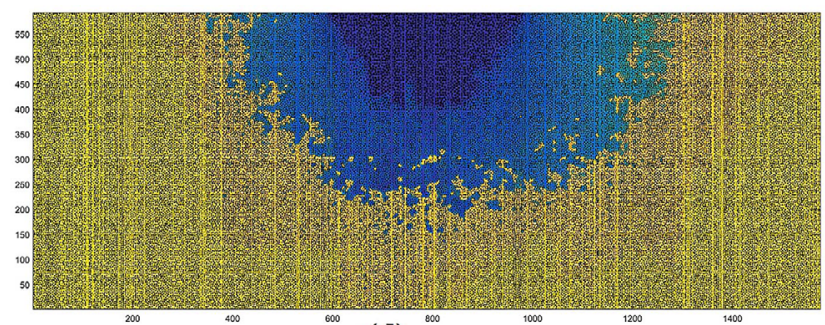

(d)

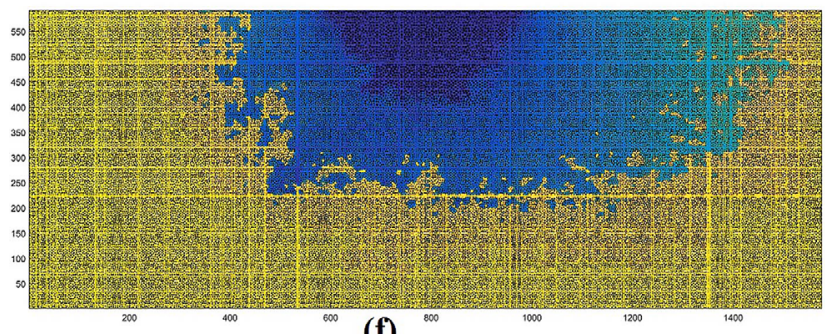

(f)

Figure 4: The effect of heterogeneity in permeability on contaminant transport at time steps of 125'ooo, (a) waste rock within homogeneous aquifer rock material, (b) tailings within homogeneous aquifer rock material, (c) waste rock in vertical fracture of aquifer rock material, (d) tailings in vertical fracture of aquifer rock material, (e) waste rock in horizontal and vertical fractures of aquifer rock material, (f) tailings in horizontal and vertical fractures of aquifer rock material

permeable waste were simulated numerically using the LBM. Induced horizontal and vertical fractures changed the permeability of the porous media from the low permeable matrix to the highly permeable fractures. These variations changed the water and dissolved solute distributions and preferential pathways of fluid flow. Three different heterogeneity scenarios in the permeability were investigated as follows:

Case 1: Homogeneous aquifer rock material and open pit filled with waste rock (WH) and tailings (TH).

Case 2: Vertical fractures in aquifer rock material and open pit filled with waste rock (WVF) and tailings (TVF).

Case 3: Horizontal and vertical fractures in aquifer rock material and open pit filled with waste rock (WHVF), and tailings (THVF).

The results of solute transport by rainfall (originated from the backfilled open pit mine) through the aquifer system are shown in Figure 3 and Figure 4, and they are discussed in the following sections.

\subsection{Case 1: Open pit filled with waste rock and tailings in the base of homogeneous aquifer rock material}

Contamination of a homogeneous aquifer system from open pit mine containing waste rock and tailings is shown in Figure 3(a,b), and Figure 4(a,b). Rainfall in the open pit acts as a continuous source of pollution. The distribution of contamination in the aquifer of the waste (case $\mathrm{WH}$ ) was greater than the pit filled with tailings materials (case $\mathrm{TH}$ ) because of the greater hydraulic conductivity of WH than TH. The head gradient between the left and the right side was enough to move the contaminant in an asymmetric downward flow.

\subsection{Case 2: Open pit filled with waste rock and tailings in the base of vertical fractured aquifer rock material}

Pollutant transport from the waste and tailings within the open pit through the vertical fractured aquifer rocks is shown in Figure 3(c,d), and Figure 4(c,d). Compared to case 1 , vertical fractures in aquifer rocks increase vertical hydraulic conductivity, and pollutants migration enhanced downward through vertical preferential pathways. The comparison between the WVF and TVF cases revealed a greater downward transport of the pollutant in the WVF case than in the TVF. It was due to the secondary vertical permeability of the waste rock and new preferential pathways for downward flow of fluids from the open pit into the aquifer rock material. As well as case 1, the hydraulic gradient between the left and the right side 
deviated the downward contaminants streamlines to the right side.

\subsection{Case 3: Open pit filled with waste rock and tailings in the base of horizontal and vertical fractured aquifer rock material}

Contaminant transport from the open pit mine containing waste and tailings materials through the horizontal and vertical fractures of the aquifer rocks is shown in Figure 3(e,f), and Figure 4(e,f). By comparing case 3 with those obtained in case 1 and case 2 , the pathways for solute transport change from the matrix pore space to the preferential pathways of the horizontal and vertical fractures. Also, an increase in the vertical and horizontal hydraulic conductivity increased the dispersion of pollutants far away from the source. In addition, the head gradient from the left side to the right side was more privileged in the dispersion of pollution because of the increase in hydraulic conductivity.

\section{Conclusions}

In the current study, a preferential pathway of contaminant transport from an open pit through a heterogeneous fracture porous media was investigated by the D2Q9 model of LBM. Three different heterogeneity scenarios in the permeability of aquifer rock material and open pit were investigated. Contamination of the homogeneous aquifer system with waste was greater than the pit filled with tailing materials. Vertical fractures in aquifer rocks increase vertical hydraulic conductivity, and pollutant migration was enhanced downward through vertical preferential pathways. An increase in hydraulic conductivity of both vertical and horizontal directions, increased the dispersion of pollutants far away from the source. The results of solute transport by rainfall (originated from the backfilled open pit mine) through the aquifer system showed: (1) grain size of open pit backfill materials that can be waste rock and tailings, affect the pollutant dispersion; (2) hydraulic gradient was another factor that controlled the speed of contamination; (3) the role of fractures were very vital in the preferential pathway of contaminant transportation.

\section{References}

Aidun, C. K., Clausen, J. R. (2010): Lattice-boltzmann method for complex flows. Annual Review of Fluid Mechanics, 42,1,439-472. doi: 10.1146/annurev-fluid-121108-145519

Aubertin, M., Bussière, B., Berner, L. (2002): Environnement et gestion des résidus miniers. Les Presses Internationales Polytechnique, Montreal, Canada, 79 p.

Barenblatt, G. I., Zheltov, I. P., Kochina, I. N. (1960): Basic concepts in the theory of seepage of homogeneous liquids in fissured rocks [strata]. Journal of Applied Mathematics and Mechanics, 24, 5, 1286-1303. doi: 10.1016/00218928(60)90107-6
Bouma, J. (1981): Soil morphology and preferential flow along macropores. Agricultural Water Management, 3, 4, 235-250. doi: 10.1016/0378-3774(81)90009-3

Brusseau, M. L., Rao, P. S. C. (1990): Modeling solute transport in structured soils: a review. Geoderma, 46, 1-3, 169 192. doi: 10.1016/0016-7061(90)90014-Z

Ehlers, W. (1975): Observations on earthworm channels and infiltration on tilled and untilled loess soil. Soil Science, 119, 3, 242-249. doi: 10.1097/00010694-197503000-00010

European Commission (2009):, Management of tailings and waste-rock in mining activities., January, European Union, $511 \mathrm{p}$.

Gerke, H. H., Van Genuchten, M. T. (1993): A dual-porosity model for simulating the preferential movement of water and solutes in structured porous media. Water Resources Research, 29, 2, 305-319. doi: 10.1029/92WR02339

Guo, Z., Shi, B., Wang, N. (2000): Lattice BGK model for incompressible Navier-Stokes equation. Journal of Computational Physics, 165, 1, 288-306. doi: 10.1006/jcph. 2000.6616

Hobbs, D. W. (1967): The formation of tension joints in sedimentary rocks: An explanation. Geological Magazine, 104, 6, 550-556. doi: 10.1017/S0016756800050226

Huang, J. (2016): Pore-scale simulation of multiphase flow using lattice Boltzmann method : developments and applications. Colorado School of Mines. Arthur Lakes Library, $99 \mathrm{p}$.

Jahanshaloo, L., Sidik, N. A. C., Fazeli, A., Mahmoud, M. P. (2016): An overview of boundary implementation in lattice Boltzmann method for computational heat and mass transfer. International Communications in Heat and Mass Transfer, 78, 1-12. doi: 10.1016/j.icheatmasstransfer.2016. 08.014

Kostenko, V., Gamiy, Y., Kostenko, T., Tsvirkun, S., Udovenko, M. (2021): Dynamics of motion of gases from a source of spontaneous combustion of coal in mine workings. Rudarsko Geolosko Naftni Zbornik, 36, 2, 109-117. doi: 10.17794/rgn.2021.2.10

Kung, K. J. S. (1990): Preferential flow in a sandy vadose zone: 2. Mechanism and implications. Geoderma, 46, 1-3, 59-71. doi: 10.1016/0016-7061(90)90007-V

Li, L. (2013): A new concept of backfill design - Application of wick drains in backfilled stopes. International Journal of Mining Science and Technology, 23, 5, 763-770. doi: 10.1016/j.ijmst.2013.08.022

Maghsoudy, S., Doulati Ardejani, F., Molson, J., Amini, M., Ebrahimi, L. (2019): Application of geo-electrical tomography in coupled Hydro-mechanical-chemical investigations in heap leaching. Mine Water and the Environment, 38, 1, 197-212. doi: 10.1007/s10230-018-0557-6

Medunić, G., Kuharić, Ž., Fiket, Ž., Bajramović, M., Singh, A. L., Krivohlavek, A., Kniewald, G., Dujmović, L. (2018): Selenium and other potentially toxic elements in vegetables and tissues of three non-migratory birds exposed to soil, water, and aquatic sediment contaminated with seleniferous raša coal. Rudarsko Geolosko Naftni Zbornik, 33, 3, 53-62. doi: 10.17794/rgn.2018.3.6

Molson, J., Aubertin, M., Bussière, B. (2012): Reactive transport modelling of acid mine drainage within discretely fractured porous media: Plume evolution from a surface 
source zone. Environmental Modelling and Software, 38, 259-270. doi: 10.1016/j.envsoft.2012.06.010

Obaje, S. O., Ogunyele, A. C., Adeola, A. O., Akingboye, A. S. (2019): Assessment of stream sediments pollution by potentially toxic elements in the active mining area of okpella, edo state, nigeria. Rudarsko Geolosko Naftni Zbornik, 34, 2, 43-49. doi: 10.17794/rgn.2019.2.5

Safari, M., Mohammadi, M., Sedighi, M. (2017): Effect of neglecting geothermal gradient on calculated oil recovery. Journal of Applied Geophysics, 138, 33-39. doi: 10.1016/j. jappgeo.2017.01.006

Safari, M., Gholami, R., Khajehvandi, E., Mohammadi, M. (2020): Temperature profile estimation: A study on the Boberg and Lantz steam stimulation model. Petroleum, 6, 1, 92-97. doi: 10.1016/j.petlm.2019.07.002

Sedighi, M., Mohammadi, M. (2018): Application of green novel NiO/ZSM-5 for removal of lead and solution: Investigation of adsorption parameters. Journal of Water and Environmental Nanotechnology, 3, 4, 301-310. doi: 10.22090/JWENT.2018.04.003

Shahhosseini, M., Doulati Ardejani, F., Amini, M., Ebrahimi, L. (2020): The spatial assessment of acid mine drainage potential within a low-grade ore dump: the role of preferential flow paths. Environmental Earth Sciences, 79, 1, 1-25. doi: 10.1007/s12665-019-8782-2

Shan, X., Chen, H. (1993): Lattice boltzmann model for simulating flows with multiple phases and components. Physical Review E, 47, 3, 1815-1819. doi: 10.1103/PhysRevE.47.1815
Shiri, Y., Hassani, H., Nazari, M., Sharifi, M. (2018): The effects of grain geometry on waterflooding and viscous fingering in micro-fractures and porous media from a lattice Boltzmann method study. Molecular Simulation, 44, 9, 708-721. doi: 10.1080/08927022.2018.1439585

Shiri, Y., Hassani, H. (2021): Two-component fluid front tracking in fault zone and discontinuity with permeability heterogeneity. Rudarsko-geološko-naftni zbornik, 36, 3, 19-30. doi: 10.17794/rgn.2021.3.2

Shiri, Y., Shiri, A. (2021): Numerical investigation of fluid flow instabilities in pore-scale with Heterogeneities in permeability and wettability. Rudarsko-geološko-naftni zbornik (The Mining-Geological-Petroleum Bulletin), 36, 3, 143-156. doi: 10.17794/rgn.2021.3.10

Therrien, R., Sudicky, E. A. (1996): Three-dimensional analysis of variably-saturated flow and solute transport in discretely-fractured porous media. Journal of Contaminant Hydrology, 23, 1-2, 1-44. doi: 10.1016/0169-7722(95) 00088-7

Vervoort, R. W., Radcliffe, D. E., West, L. T. (1999): Soil structure development and preferential solute flow. Water Resources Research, 35, 4, 913-928. doi: 10.1029/98WR 02289

Zhou, Y., Zhang, R., Staroselsky, I., Chen, H. (2004): Numerical simulation of laminar and turbulent buoyancy-driven flows using a lattice Boltzmann based algorithm. International Journal of Heat and Mass Transfer, 47, 22, 48694879. doi: 10.1016/j.ijheatmasstransfer.2004.05.020

\section{SAŽETAK}

\section{Simulacija zagađenja podzemnih voda s mjesta odlaganja rudarskoga otpada}

Rudarski otpad velik je izvor onečišćenja. Kao materijali za zatrpavanje otvorenih jama mogu se koristiti otpadne stijene i jalovina. Cilj ove studije bio je istražiti putove transporta onečišćenja podzemnim vodama iz ovih otpadnih materijala kroz heterogene porozne medije. Boltzmannova metoda numeričke rešetke (LBM) korištena je za određivanje učinaka različitih čimbenika na transport onečišćujućih tvari kroz podzemne vode ispod otpadnih materijala. Čimbenici koji su uzeti u obzir bili su veličina zrna, okomite i vodoravne pukotine te hidraulički gradijent tlaka. Rezultati su pokazali da prijenos onečišćenja protokom podzemnih voda iz otpadnih materijala kroz porozne medije ovisi o poroznosti primarne i sekundarne matrice otkopanih materijala, heterogenosti propusnosti stijene vodonosnika i hidrauličkom tlaku podzemne vode.

\section{Ključne riječi:}

metoda Lattice-Boltzmann, povratno difuzijsko zagađenje, slabo propusne leće, sanacija vodonosnika, medij dvostruke propusnosti

\section{Author's contribution}

Mojtaba Dehqani Tafti (Student, PhD, Mining Engineering) provided the interpretations and writing the manuscript. Faramarz Doulati Ardejani (Professor, PhD, Mining Engineering) provided the interpretations and presentation of the results. Mohammad Fatehi Marji (Professor, PhD, Mining Engineering) provided the interpretations and presentation of the results. Yousef Shiri (Assistant Professor, PhD, Petroleum Engineering) provided the numerical code and some analyses. 